\title{
САЛАФИТСКИЙ ЦИВИЛИЗАЦИОННЫЙ ПРОЕКТ В ТРОПИЧЕСКОЙ АФРИКЕ
}

\section{SALAFI CIVILIZATION PROJECT IN TROPICAL AFRICA}

\section{R. Bobokhonov}

Summary: In this paper, we will consider a Salafi civilization project in Tropical Africa. We will try to understand in what format and with what human resources the Salafi movement in Tropical Africa conducts its activities. We will also try to understand why in recent years Salafism has been so actively penetrating these countries, where various Sufi tariqas have functioned successfully for many centuries. We will try to understand what alternative civilizational model of the world order Salafism offers to the whole world, including the countries of Tropical Africa. It should be noted that Salafism declared Sufism - "unfaithful Islam" and therefore began to actively fight against it throughout the world, including in Tropical Africa.

Keywords: Salafism, Wahhabism, Sufism, Sufi tariqas, radical currents of Islam, Islamism, Salafi civilization project.

\author{
Бобохонов Рахимбек Сархадбекович \\ С.н.с., Центр цивилизационных и региональных \\ исследований Института Африки РАН \\ rahimbobokhonov@yandex.ru
}

Аннотация: В данной работе мы рассмотрим салафитский цивилизационный проект в Тропической Африке. Мы попытаемся понять, в каком формате и располагая какими людскими ресурсами ведет свою деятельность салафитское движение в Тропической Африке. Мы попытаемся также понять, почему в последние годы салафизм так активно проникает в эти страны, где на протяжении многих веков успешно функционировали различные суфийские тарикаты Мы постараемся понять, какую альтернативную цивилизационную модель мирового порядка предлагает салафизм всему миру, включая страны Тропической Африки. Следует отметить, что салафизм объявил суфизм бидъой - «неверным исламом» и поэтому стал активно бороться против него по всему миру, в том числе и в Тропической Африке.

Ключевые слова: салафизм, ваххабизм, суфизм, суфийские тарикаты, радикальные течения ислама, исламизм, салафитский цивилизационный проект.
$\mathrm{B}$ период «арабской весны» в мировых СМИ стали больше писать о салафитах, подъеме салафитских движений, салафитского цивилизационного проекта не только на Ближнем Востоке и Африке, но и во всем мире. Интерес к этой теме возрос после того, как салафитское движение впервые включилось в политическую борьбу за власть в Египте и Алжире. Новые политические организации салафитского толка формировались в основном из числа молодых и энергичных людей. По сути, они являлись радикальными молодежными организациями, которые не только участвовали в митингах и шествиях под руководством «Братьев-мусульман», но и самостоятельно боролись за власть под лозунгами салафитских партии «Ан - Нур», «Аль - Ватан» и «Фронт реформ» [1]. Салафиты также являются активными членами таких радикальных и террористических организаций по всему миру, как: «Аль Каида», «Талибан», «Хизб-ат Тахрир», «Братья мусульмане», «Боко харам», «Аш - Шабаб», «Селека», «Ансар ад-дин»(запрещённые в РФ) и т.д. Салафизм стал распространяться по всему миру прежде всего в результате активной деятельности вышеназванных организаций. В Тропическую Африку салафизм проник при поддержке «Аль Каиды», «Боко харам», «Аш -Шабаб», «Селека», «Ансар ад-дин» и т.д. [2].

Каково же историческое прошлое салафизма, когда, кем и почему он был востребован в цивилизационном, религиозном и идеологическом формате? В относитель- но недавнем историческом прошлом, во время подъема ваххабитского религиозно - политического движения за освобождение Саудовской Аравии от Османского халифата идеолог и предводитель этого движения Мухаммад аль - Ваххаб называл себя приверженцем классического салафизма. После распада Османского халифата салафизм, как и ваххабизм, стал официальной религиозноидеологической доктриной Саудовской Аравии [3].

Некоторые исследователи политической истории ислама склонны думать, что классический салафизм по многим параметрам все-таки отличается от ваххабизма. Более того, эта точка зрения в последнее время распространяется в СМИ, особенно на социальных сайтах Интернета. Почему об отличиях салафизма от ваххабизма стали говорить и писать именно в последние годы? На наш взгляд, это связано с последствиями «арабской весны» и усилением роли радикального политического ислама (исламизма) во всем мире. Отметить, что после «арабской весны» многие салафиты перебрались в Сирию, где в результате политизации ислама возникло так называемое Исламское государство (запрещенное в РФ) [4]. Очень быстро салафиты - джихадисты стали главной военной и политической силой в «Исламском государстве» (ДАИШ). США и их союзники по НАТО в 2014 году объявили войну «Исламскому государству». В ноябре 2015 года РФ включилась в эту войну по приглашению правительство Сирийской республики [5]. 
В Саудовской Аравии, которая в течении многих лет является союзником США в регионе Ближнего Востока, власть и духовенство начали отмежеваться от радикальных салафитов-джихадистов. В связи с этим, возможно, по инициативе официальных кругов Саудовской Аравии была распространена идея, отрицающая единство ваххабизма и салафизма. Однако следует отметить, что Саудовская Аравия на протяжении XX века не только вырастила огромную армию салафитов, но и успешно экспортировала салафизм по всему миру. Салафизм начал распространяться в Африке под влиянием многих мусульманских неправительственных организаций (NGO), таких как «Мировая мусульманская лига», «Всемирная ассамблея для мусульманской молодежи», «Федерации Мэб и исламских школ», прежде всего финансируемых салафитскими правительствами на Ближнем Востоке. Эти салафитские организации, часто базирующиеся в Саудовской Аравии, продвигают консервативный и классический салафизм в Африке, поскольку расценивают традиционный суфийский ислам в этом регионе как неверный и не настоящий ислам. Об этом подробнее в работе автора «Роль и перспективы радикального ислама после арабской весны» [6].

Перейдем к анализу позиций салафизма в Тропической Африке. В ходе и после событий «арабской весны», как было отмечено выше, возросла роль салафитского движении не только в Северной, но и в Тропической Африке. Помимо активного участия в радикальных течениях ислама, таких как «Боко харам», «Аш-Шабаб», «Ансар ад-дин», «Селека» и другие, многие салафиты включились в мировой сетевой ислам. Самыми активными и посещаемыми исламскими сайтами стали салафитские. В отличие от «Братьев - мусульман», которые непосредственно включились в политическую борьбу в реальной жизни в Египте и Тунисе, салафиты начали свою борьбу в социальных сайтах Интернета. Более того, салафиты раньше всех подключились к мировому сетевому исламу, поскольку агитацию и пропаганду «чистого ислама» они вели на протяжении всего XX века. Появление Интернета и социальных сайтов открыло салафитам новые важные трибуны для продвижения своих идей в мировом информационном пространстве.

В отличие от старшего поколения идейных салафитов, которые мирно распространяли свои идеи в мечетях, в религиозных школах, медресе и университетах, молодые салафиты в социальных сайтах объединялись не только идейно, но и политически, занимая враждебную позицию по отношению к другим религиозным партиям и организациям во всем мусульманском мире. Таким образом, в онлайн-пространстве постепенно формировалось джихадистское направление салафизма, его сторонник выходило на улицу, чтобы реализовать свои идеи вооруженным путем. Для реализации своих идей салафиты - джихадисты выбрали две страны -Тунис и Египет; правда, в этом им помешали «Братья - мусульмане», которые пришли к власти и хотели постепенно отмежеваться от всего салафитского движения в ближайшей перспективе [7, с. 41-46]. Но салафиты в Тропической Африке начали реализовывать свои идеи в ходе вооруженной борьбы в составе радикальных и исламистских организации - в Нигерии(«Боко харам»)[2], Сомали, Кении, Танзании(«Аш-шабаб»)[8], в Мали(«Ансар ад-дин») [9], в Центрально-Африканской Республике («Селека») [13] и т.д. Основную борьбу в странах Тропической Африки салафиты развернули против светских государств, против христианского населения, суфийского ислама и его исторического наследия (святых и культовых сооружений, мазаров, медресе, библиотек с архивными рукописями и т.д.).

Основные черты салафизма в Тропической Африке таковы: создание отделенных от других мусульман общин; отказ от традиционных форм почитания старших и уважения марабутов; отказ от культа святых; обращение исключительно к Корану и Сунне Пророка в качестве источников веры; демонстративно выражаемое недоверие к любым (за исключением исламской) правовым системам; враждебное отношение к тарикатам, которые расцениваются «пуританами ислама» как новаторские и еретические секты, искажающие смысл и содержание веры. Все мировые религии, включая классический ислам, призывают к самосовершенствованию, к «работе над собой». Приверженцы салафизма априори «безгрешны», их основная задача - «исправить других». Там, где получают распространение подобные формы ислама, возникают свои собственные органы самоуправления, там имущественные, семейные и уголовные проблемы решаются лидером местной мусульманской общины на основе норм шариата. Представители действующей светской власти встречаются с населением только на свадьбах и похоронах. Салафитские проповедники всегда среди простых людей [9].

Религиозное учение африканских салафитов делит мир на «дар уль ислам» - «мир ислама», территорию, где действует религиозный закон и где политически господствуют мусульмане, и «дар уль харб» - «мир войны», территорию, где исламский закон не действует, где мусульмане подвергаются притеснениям и ислам еще не утвердился. Главная задача мусульманской уммы, с точки зрения салафитов, - стремиться к тому, чтобы «дар уль харб» превратился в «дар уль ислам». Пути к этой цели могут быть разными - военные завоевания, проповеди истинной религии - ислама и добровольное обращение населения в эту религию.

Другим важнейшим принципом салафитской доктрины в Тропической Африке является джихад, который трактуется как усердие, старание, любая форма деятель- 
ности мусульман (индивидуальная или коллективная), направленная на следование человека по пути Аллаха. Он обязателен абсолютно для всех мусульман. Джихад разделяется на большой и малый. Большой джихад борьба со своими собственными отклонениями от пути Аллаха. Малый - «джихад меча», он может проявляться в двух формах. Наступательный джихад - распространение ислама на «дар уль харб». Оборонительный джихад объявляется при угрозе исламу или нападении на «дар уль ислам». Принцип джихада отвергает все законы старого мира неверных и призывает к революционной борьбе за торжество ислама. При этом джихад трактуется как применение насилия в разных формах для достижения религиозного идеала [7, с. 41-46].

Такова цивилизационная модель общественного устройства, которую салафиты предлагают в Тропической Африке. Основная политическая цель при этом - путем джихада - вооруженной борьбы построить исламское государство в странах этого региона. Главный враг в регионе не христиане, а представители суфизма, которые исповедуют, по мнению салафитов, неверный и не подлинный ислам. Традиционные мусульманские объединения - духовные ордены (тарикаты) мирно сосуществуют с христианами и местными правителями, не хотят бороться за исламское государство. Поэтому салафиты для реализации своего глобального проекта - создания Всемирного халифата выдвигают главную задачу - вытеснить и уничтожить суфийский ислам в регионе. В политических установках и программах салафитских группировок отличаются тем, что в их учении, которое они расценивают как единственно правильную трактовку ислама, присутствуют два непременных системообразующих, присущих салафизму положения: о такфире (обвинение в неверии - куфр - всех мусульман, кто не согласен с салафитами) и о джихаде, который преподносится как вооруженная борьба, вменяемая в обязанность каждому мусульманину, против неверных (кяфиров). Необходимо при этом иметь в виду, что данные термины - не просто оценочные характеристики, а шариатско-правовые категории. Их использование по отношению к тому или иному мусульманину или группе мусульман предполагает обязательность применения конкретных санкций. Под эти санкции, конечно, попадают представители традиционного ислама - суфизма.

Каковы же особенности суфийского ислама в Тропической Африке, против которых выступают салафиты? Суфийские тарикаты, как правило, лояльно относятся ко многим запретам в исламской религии. Например, практически во всей Тропической Африке не соблюдаются запреты на изображение живых существ. Скульптурные изображения людей и животных и другая мелкая пластика являются неотъемлемым атрибутом традиционных религиозных культов у подавляющего большинства аф- риканских народов, а также основным видом туристических сувениров. А ритуальные церемонии с использованием масок предков, духов и демонов проходят даже в мечетях. В мусульманских африканских семьях девочкам разрешают играть в куклы, изображающие людей. Также часто нарушаются пищевые запреты. Например, среди мусульман - темне в Сьерра-Леоне свинья почитается как тотемное животное. Там, где в доисламский период тотемными животными были собаки, их продолжают почитать и в настоящее время. Не считается из ряда вон выходящим употребление во время поста еды, напитков, табака, алкоголя и наркотических веществ. Сами африканские мусульмане часто говорят об «исламизации» без «арабизации».

Провозглашая равенство в вере, аскетизм, тарикаты постепенно становились активными и самостоятельными участниками экономической жизни, продолжая миссионерскую деятельность первых мусульманских купцов, сочетавших духовные и мирские цели и выполнявших от имени Аллаха требования просветительского, этического и экономического характера. В результате устанавливался новый характер социальных связей, когда кровнородственные и общинно-родовые отношения, бывшие многие века основой единства общества, заменялись отношениями духовной близости и экономической подчиненности руководителям тарикатов. Марабуты [14], мудрецы и знатоки Корана, обладавшие харизмой и (барака), одновременно были и удачливыми бизнесменами. Необходимо учитывать и длительную временную протяженность деятельности тарикатов в ряде стран Тропической Африки. Старейший тарикат Кадирия был основан в XII в. За прошедшее время от него отпочковалось до сотни самостоятельных тарикатов.

Соблюдение достаточно строгой иерархической дисциплины и послушание приверженцев главе тариката позволили некоторым из них со временем занять сильные позиции в торговле, сельском хозяйстве и даже банковском деле во многих странах Западной Африки, особенно в Сенегале. Сегодня тарикаты - не только религиозные институты, но и влиятельная политическая, экономическая, социальная сила, которая оказывает непосредственное влияние на функционирование и развитие многих западноафриканских государств [15, с. 44-55].

Для африканцев, сильно тяготеющих к традиционным культам и обрядам, влияние и деятельность марабутов компенсируют безликость монотеистического божества. Они считаются своего рода посредниками между богом и человеком, на них смотрят как на людей, наделенных благодатной силой - барака. В Африке существует убеждение, что она может передаваться при непосредственном контакте людей. Поэтому могилы особенно известных при жизни марабутов, а также руководителей тарикатов, которым приписываются такие же качества 
марабутов, становятся местом паломничества, а предметы, которыми они пользовались, приобретают ценность сакральных реликвий. Власть в тарикатах, которые были основаны марабутами, наделенными баракой, передается по наследству. Марабуты одновременно воспринимаются как колдуны, ясновидящие, целители. Значительная часть их религиозной активности посвящена созданию амулетов, талисманов, которые являются непременным атрибутом подавляющего большинства верующих. Среди сенегальских мусульман распространена пословица: «Обеспечить безопасность двумя способами лучше, чем одним» $[12$, с. 55]. Эти и другие черты суфийского ислама в Тропической Африке, конечно, сильно раздражают салафитов и, согласно такфиру, дают им основание объявлять не соблюдающих нормы ислама неверными. Салафитский джихад - это и есть борьба против неверных.

Как мы видим, цивилизационные вызовы салафизма в Тропической Африке направлены не только против местных христиан, существующих там государств и правителей, но и против мусульман, которые являются последователями различных суфийских тарикатов.

Нигерийские салафиты из группировки «Боко харам» исходят из положения об абсолютной власти Аллаха над всем сущим на Земле и над людьми. Власть в обществе должна принадлежать религиозным деятелям, разделяющим идеи «истинной веры», т.е. халифу Исламского государства и его приближенным. Настоящие лидеры не назначаются, и не избираются, даже внутри уммы, а выделяются самим Аллахом. Власть исходит из ниспосланной свыше некой божественной сверх идеи, которая существует независимо от людей и помимо их воли. Истинным верующим является тот, кто правильно ее понимает, т.е., говоря современным языком, обладает монополией на истину. Все остальные, включая подавляющее большинство мусульман, являются «язычниками», так как им не хватает истинной религиозности. Они лишь внешне копируют обряды поклонения Аллаху, но не понимают природу божественности. Именно поэтому в настоящее время человечество вернулось в период доисламского невежества (джахилийя), которое опаснее и греховнее предыдущего. Подлинное предназначение «Боко харам»- помочь «заблуждающимся» и «язычникам» обрести истинную веру. Для этого приемлемы любые пути, а цель оправдывает средства ее достижении $[2]$.

Члены группировки «Ансар ад-Дин» («Защитники веры» в переводе с арабского), удерживающие под своим контролем обширную территорию на севере Мали, разрушили в древнем городе Томбукту памятники архитектуры, культуры и истории ислама, внесенные в список Всемирного наследия ЮНЕСКО. В этот перечень были включены, в частности, три мечети, главное медресе Томбукту и 16 из 333 захоронений шейхов, кото- рых почитают как аулия (приближенные к Аллаху. - Р.Б.). Одно из захоронений - Сиди Махмуда (Бен Амара) - существовало с 1548 года. Следует отметить, что разрушение гробниц - не первый акт вандализма со стороны «ансаров» в Мали. Весной 2012 года они подожгли одну из мечетей и разграбили основанный в 1973 году Центр сбора архивных документов и исследований имени Ахмеда Бабы. По данным министерства культуры Мали, в библиотеке Центра хранилось от 60 до 100 тысяч средневековых рукописных свитков, содержавших бесценную информацию о развитии и истории ислама в Западной Африке. Вообще в Томбукту хранится около 300000 манускриптов мусульманской цивилизации в Африке. Город, который был основан еще в XI веке, благодаря таким «защитникам» ислама, оказался под угрозой полной утраты своего великого исторического наследия [16].

В Сомали между 2004 и 2006 годами образовалась салафитская вооруженная группировка «Аш-Шабаб». На тот момент страна уже около 15 лет находилась в состоянии тяжелой гражданской войны. Название организации означает «молодость» в переводе с арабского. «Аш-Шабаб» борется за создание исламского государства в районе Африканского Рога. Ее радикально-джихадистская идеология не знает государственных границ. В настоящее время группировка совершает нападения на территории всей Восточной Африки, например, В столице Кении Найроби, здесь во время налета на торговый центр в 2013 году было убито более 60 человек. «Аш-Шабаб» контролирует территорию в центре и на юге Сомали. Лидеры организации подчеркивают, что сотрудничают с «Аль-Каидой» при подготовке боевиков. Кроме того, группировка имеет связи с радикальными исламистами из группировки «Боко Харам» [17].

Религиозный конфликт в Центрально-Африканской Республике представляет собой довольно сложную структуру: с одной стороны находится правительственная власть ЦАР, с другой - повстанческие группировки, представляющие христианскую и мусульманскую общины страны. Салафитский альянс повстанцев «Селека» включает в себя несколько террористических группировок, ныне базирующихся на северо-востоке страны. В принципе, именно «Селека» в 2013 году произвела государственный переворот, захватив сначала несколько городов, а затем и президентский дворец в городе Банги. После переворота глава «Селеки» Мишель Джотодия провозгласил себя президентом страны. Власть практически была захвачена только в Банги, а на остальной территории страны, по свидетельству наблюдателей $\mathrm{OOH}$, «государства фактически не было». Иными словами, за пределами столицы не было никакой безопасности и законности: не было ни полицейских, ни прокуроров, ни судей. В стране стали орудовать бойцы «Селеки», которые занимались грабежам и вымогательством, причем 
только в отношении христианского населения. Затем салафиты «Селека» начали выступать против суфизма во всех его проявлениях [11].

Наш анализ показывает, что в последние годы джихадистский салафизм все больше распространяется в Тропической Африке. У джихадисткого салафизма четко определены цели и задачи. «Аль Каида» и его подразделения хорошо финансируют салафитов по всей Африке. Для достижение главной цели - создание исламского государства нужны не только финансовые, но и людские ресурсы. Поэтому салафитские группировки пытаются объединиться, чтобы иметь более сплоченную структуру для захвата власти в странах региона. В последние годы часто к салафитам присоединяются молодые ученики суфийских тарикатов, таким образом, они пытаются уходит от жесткого преследования воинствующих салафитов. Здесь мы видим рустующую роль салафизма в религиозных интеграционных процессах в мусульманских обществах региона. Следует отметить, что этот интеграционный процесс имеет принудительный и насильственный характер, но его темпы довольно ощутимы в странах Тропической Африки. Эти интеграционные процессы имеют двоякую цель: с одной стороны, объединиться под знаменем джихада для создание исламского государства, с другой стороны, бороться против христиан и тарикатов, которые, по мнению салафитов, не являются настоящими мусульманскими течениями в исламе. Таким образом, салафизм в последние годы не только контролирует, но и руководит религиозными интеграционными процессами в мусульманских обществах Тропической Африки.

Российский исламовед А.Д. Саватеев впервые начал писать о рустующем роли салафизма в странах Тропической Африки в начале XXI века. Более того, он рассуждает о системном и духовном кризисе суфийского ислама в регионе. По его мнению, этот кризис спровоцировал исламизм и салафизм. Подробнее в работе автора [18].

Страны Тропической Африки, конечно, не готовы к приходу исламизма и салафитского джихада. Не готовы христиане и тарикаты. Светские африканские режимы раньше опирались на поддержку тарикатов и их шейхов, которые имели огромные авторитеты среди местного мусульманского населения. Теперь эти шейхи бояться салафитов и не могут поддерживать руководителей этих стран. Диалог и спор между салафитами и тарикатами по многим политическим, экономическим и религиозным вопросам, как правило, заканчивается в пользу салафитов. Между существующих режимов и салафитов никакого мирного диалога не происходит, идет война «Аль Каиды», «Боко харама», «Аш -Шабаба», «Селеки», «Ансар ад -дина» и т.д. против местных властей на протяжении мно- гих лет. Процессы радикализации ислама и вытеснение мирного суфийского ислама в регионе исключают какого угодно диалога между воюющих сторон и наступление мира. Прогнозы не утешительны, поскольку джихадистское направление салафизма явление относительно новое и оно, возможно, еще много лет будет вызревать, пока не наступит кризис и не уходит из политической и религиозной жизни общества.

Тем не менее, в последние годы реакция международного сообщества на происходящих событий в странах Тропической Африки в связи с ростом исламизма и салафизма, стала более заметна. Создаются разные программы по дерадикализации исламистских группировок в странах региона. Опыт по дерадикализии «Боко харам» оказался неудачным. Военные рейды со стороны разных стран против пиратов «Аш - Шабаба» в Сомали проводятся регулярно, иногда с успехом. Страны региона часто создают объединенные вооруженные силы против исламистов в Сомали, Нигерии, Мали, Камеруне и Чаде, но истребить и уничтожит боевиков салафитского джихада им не по силу. Исламизм, терроризм и бандитизм в некоторых мусульманских Тропической Африки, попрежнему, продолжается.

Создается ощущение, что движение салафитского ислама утвердилось в Тропической Африке всерьез и надолго. Это начинают понимать даже руководители тех стран Африки, где еще не так давно вообще не было мусульман. Например, руководители Анголы, в соответствии с действующим законодательством страны, в 2015 г. запретили ислам и снесли все мечети [19]. Даже если будут ликвидированы салафитские группировки «Боко харам», «Аш-Шабаб», «Ансар ад-дин», «Селека» и другие, то им на смену в любом африканском мусульманском обществе обязательно придут аналогичные организации. Идеологию невозможно победить с помощью оружия. Она может утратить свое влияние на массы только в том случае, если они воспримут иное учение.

В заключение следует отметить, что в последние годы ислам стал составной частью социально-экономической и политической жизни многих стран Африки, и рост его влияния может существенно изменить цивилизационный облик многих из них. Мусульманские социально-политические институты не только воздействуют на соответствующие государственные структуры, но и выступают иногда как наиболее действенная им альтернатива. Все активнее становятся силы, ратующие за построение общества, основанного на исламских законах и духовных ценностях. Рустующие вызовы салафизма могут изменить баланс социально-экономических, политических, религиозных сил и усилить цивилизационный кризис в Тропической Африке. 


\section{ЛИТЕРАТУРА}

1. Бобохонов Р.С. Кризис авторитарных режимов в арабских странах и опыт демократических изменений в современном мусульманском мире //Протестные движения в арабских странах: Предпосылки, особенности, перспективы. М., 2012.

2. Бобохонов Р.С. Радикальные течения ислама в мире: "Боко харам" Центральная Азия. 5. 9. 2017. Постоянный электронный адрес статьи: http: // www. centrasia. ru / news. php? St $=1504600680$.

3. Бобохонов Р.С. История исламского фундаментализма // www. centrasia.ru/ newsA.php?st=1447276380.

4. Бобохонов Р.С. Возникновение ИГИЛ - как результат активной политизации ислама // www. centrasia. ru / newsA.php?st = 1419067980.

5. Российская операция в Сирии: уйти нельзя// www. bbc. Com / russian / russia / 2015 /.../ 151012 _qd_russian_syria_operatio.

6. Бобохонов Р.С. Роль и перспективы радикального ислама после арабской весны // http:// www.centrasia.ru/ newsA.php?st =1378474380.

7. Бобохонов Р.С. Участие радикальных исламистских движений в современных африканских конфликтах: религиозная и нерелигиозная составляющие (на примере организации "Боко Харам") // Сборник материалов "Религиозные конфликты в Африке южнее Сахары: угрозы нарастания и возможности предотвращения". Москва: Институт Африки РАН, 2019 С. 41-46.

8. Бобхонов Р.С. Радикальные течения ислама в мире - Аш-Шабаб//Современная наука: актуальные проблемы теории и практики. Серия "Гуманитарные науки". №8. 2018, с.8-13.

9. Бобохонов Р.С. Радикальные течения ислама в Африке: Ансар ад-дин. Мали// Современная наука: актуальные проблемы теории и практики. Серия «Гуманитарные науки». №6/2. 2020, с.8-14.

10. Бобохонов Р.С. Радикальные течения ислама в Африке: «Селека»//Современная наука: актуальные проблемы теории и практики. Серия «Гуманитарные науки». - №8. -2019. -С.6-16.

11. Бобохонов Р.С. Радикальные течения ислама в Африке: Ансар ад-дин. Мали// Современная наука: актуальные проблемы теории и практики. Серия «Гуманитарные науки». №6/2, 2020, с.6-10.

12. Бобохонов Р.С. Участие радикальных исламистских движений в современных африканских конфликтах: религиозная и нерелигиозная составляющие (на примере организации "Боко Харам") // Сборник материалов "Религиозные конфликты в Африке южнее Сахары: угрозы нарастания и возможности предотвращения". Москва: Институт Африки РАН, 2019 С. 41-46.

13. Мусульманский священнослужитель, "живой святой"; ранее - аскет, готовивший себя для войны за веру.

14. Емельянов А.Л. Черный ислам // Новая и новейшая история. - 2016. - № 1. - С. 44-55.

15. Мухаметов А.Р. Члены движения Ансар ад-дин уничтожают памятники в Мали// https://golosislama.com/news.php?id=9939.

16. Кто есть кто в мире радикального ислама//Политика и общество//DW. 01.07.2014.

17. Саватеев А.Д. Мусульманские духовные ордена в Тропической Африке / Ученые записки Институт Африки РАН, выпуск 13. М.: Издательский дом XXI век - Согласие, 1999. - 152 с.

18. Запрет ислама в Анголе может иметь глобальные последствия//Рамблер. 08.09.2015. 